\title{
MOBILE TOUR SYSTEM OBJEK WISATA ISTANA SIAK SRI INDRAPURA BERBASIS ANDROID
}

\author{
${ }^{1}$ Zarnelly, ${ }^{2}$ Deswanto \\ 1,2Program Studi Sistem Informasi, Fakultas Sains dan Teknologi, UIN SUSKA Riau, \\ Jl. HR Soebrantas, KM. 18.5, No. 155, Simpang Baru, Pekanbaru, Indonesia, 28293. \\ Email: 1'zarnelly@uin-suska.ac.id, 2deswanto99@gmail.com.
}

\begin{abstract}
ABSTRAK
Istana Siak adalah salah satu objek wisata di Kabupaten Siak yang memiliki potensi wisata sejarah sangat besar karena merupakan peninggalan kerajaan melayu pada tahun 1723 M. Informasi tentang objek wisata Istana Siak pada saat ini belum terkelola secara maksimal. Saat ini informasi yang tersedia masih menggunakan website, brosur, event wisata dan pramuwisata. Jumlah pramuwisata di Istana Siak berjumlah 13 orang yang bertugas untuk memandu wisatawan yang sedang berkunjung. Jumlah tersebut masih kurang jika pengunjung Istana Siak sedang ramai sehingga membuat wisatawan berkeliling tanpa ditemani pramuwista. Penelitian ini bertujuan untuk membangun mobile tour system yang memudahkan wisatawan dalam mendapatkan informasi ketika berkunjung ke Istana Siak secara cepat. Metode pengembangan sistem menggunakan object oriented anaysis and design (OOAD). Sistem dibuat menjadi 2 bagian yakni sistem back end berbasis web untuk pengelola Istana Siak; dan sistem front end berbasis Android untuk wisatawan. Hasil dari pengujian blackbox dapat disimpulkan bahwa sistem mampu berjalan dengan sangat baik dengan tingkat keberhasilan $100 \%$. Hasil dari user acceptance test menunjukkan tingkat penerimaan pengguna adalah baik, yaitu sebesar $70 \%$.
\end{abstract}

Kata Kunci: Android, istana siak, mobile tour system, wisata sejarah

\section{A. PENDAHULUAN}

Kabupaten Siak dikenal dengan kerjaan melayu terbesar yakni Kerajaan Siak yang berkembang pesat pada tahun $1723 \mathrm{M}$. Hal ini dapat dibuktikan dengan masih banyak situs-situs sejarah peninggalan Kerajaan Siak yang terdapat di Kabupaten Siak yang salah satunya adalah Istana Asserayah Al-Hasyimiah atau lebih dikenal dengan nama Istana Siak dengan sebutan Istana Matahari Timur yang dibangun pada tahun 1889. Berdasarkan Keputusan Menteri Kebudayaan dan Pariwisata nomor: KM.13/PW/PW.007/ MKP/2004 telah menetapkan Istana Siak sebagai benda cagar budaya, situs atau kawasan yang dilindungi Undang-Undang Republik Indonesia Nomor 5 Tahun 1992. Potensi sektor pariwisata menjadi salah satu aset besar bagi Kabupaten Siak untuk mengembangkan kepariwisataan Siak. Potensi pariwisata Kabupaten siak ini dapat dijadikan sebagai salah satu penghasil devisa bagi pemerintah maupun masyarakat setempat. Namun diantara berbagai potensi wisata yang ada, potensi wisata yang paling banyak dikunjungi atau digemari wisatawan adalah Istana Siak [1].

Bagi pemerintah daerah ini merupakan salah satu aspek untuk meningkatkan pendapatan daerah. Salah satu kendala yang dihadapi oleh pemerintah daerah dalam hal pemasaran objek wisata Istana Siak adalah tidak adanya penyampaian informasi yang efektif dan efisien untuk para wisatawan. Dalam penyampaian informasinya, memang Dinas Pariwisata memiliki website akan tetapi kurang memadai dalam memberikan informasi tentang objek wisata Istana Siak, selain itu dinas pariwisata masih menempuh cara konvensional, seperti pemberian brosur, leaflet dan booklet.

Selain media tersebut dalam memberikan penjelasan kepada wistawan yang berkunjung masih menggunakan media berupa kuningan yang tercetak disetiap objek. Hal tersebut kuranglah efektif, walaupun banyak teknologi canggih yang sudah tersedia, akan tetapi tetapi belum dimanfaatkan secara maksimal dan wisatawan masih sering mengalami kesulitan dalam mendapatkan informasi sejarah, peninggalan atau yang berkaitan dengan istana siak lainnya.

Saat ini pramuwisata yang terdapat di Istana Siak yaitu terdapat 13 pramuwisata di mana keseluruhan jumlah pramuwisata tersebut bisa dikatakan tidak terlalu memadai dalam melakukan pelayanan terhadap pengunjung yang ramai terutama pada hari libur dan pramuwisata yang ada tidak memiliki lisensi sebagai pramuwisata profesional yang terdaftar secara sah yang diterbitkan oleh Himpunan Pramuwisata Indonesia (HPI), di mana sebagian yang menjadi pramuwisata yang ada merupakan orang yang telah lama berada di Siak, secara keseluruhan pramuwisata yang ada merupakan pekerja Honorer dulunya dan sekarang sebagian telah menjadi PNS, bahkan sebagiannya bisa dikatakan merupakan orang yang tidak mempunyai basic pendidikan pramuwisata [2].

Untuk mengatasi permasalahan-permasalahan tersebut diperlukan adanya upaya yang 
memudahkan untuk memberikan informasi tentang objek wisata Istana Siak kepada wisatawan yang berkunjung, yakni dengan menyatukan/ mengintegrasikan perkembangan teknologi saat ini. Quick response (QR Code) merupakan evolusi teknologi yang dapat menjawab permasalahan di atas. Quick response (QR Code) merupakan sebuah kode batang dalam dua dimensi yang memiliki kemampuan menyimpan data atau informasi lebih banyak jika dibandingkan dengan kode batang satu dimensi.

Pemanfaatan teknologi $Q R$ Code dibuat dengan tujuan untuk menyimpan berbagai macam informasi yang ada didalam Istana Siak sehingga penggunaan QR Code dalam memudahkan mamandu wisatawan ketika berkunjung tanpa menggunakan pramuwisata, wisatawan cukup melakukan scan QR Code yang terdapat disetiap objek didalam Istana Siak.

\section{B. METODOLOGI PENELITIAN}

B.1. Tahap Pengumpulan Data

Tahap ini merupakan tahap dalam mendapatkan sumber data yang berkaitan dengan masalah yang diangkat. Tahapan ini meliputi Observasi, Wawancara dan Studi Pustaka.

\section{B.2. Tahap Analisa dan Perancangan}

Tahap selanjutnya dalam metodologi penelitian ini adalah tahap analisa yang terdiri dari: analisa sistem berjalan, analisa sistem usulan, analisa kebutuhan, pembuatan arsitektur sistem, pembuatan model dengan UML, pembuatan desain struktur menu dan pembuatan desain interface.

\section{B.3. Tahap Implementasi dan Pengujian}

Tahap implementasi merupakan tahap yang dilakukan setelah membuat rancangan sistem. Kegiatana yang dilakukan adalah pembuatan coding program dan pengujian black box dan UAT.

\section{HASIL DAN PEMBAHASAN \\ C.1. Sistem Yang Berjalan}

Ilustrasi sistem yang sedang berjalan dapat dilihat pada Gambar 1. Pada proses memberikan informasi objek wisata Istana Siak kepada wisatawan yang telah dilakukan oleh Dinas Pariwisata Kabupaten Siak sebagai berikut:

(1) Periklanan (Advertising) yang meliputi penyampaian informasi melalui media cetak, media elektronik dan media website.

(2) Promosi penjulan (Sales Promotion) yang meliputi brosur-brosur, leaflet, booklet, pameran, shopping bag, stiker dan pin.

(3) Penjualan Peseorangan (Personal Selling) meliputi kejelasam dalam menyampaikan informasi, kemampuan berkomunikasi dan terbuka dalam memberikan pelayanan.

(4) Hubungan Masyarakat (Public Relation) yang meliputi kerjasama dengan hotel, kerjasama dengan objek wisata, kerjasama dengan pemerintah dan kerjasama dengan masyarakat

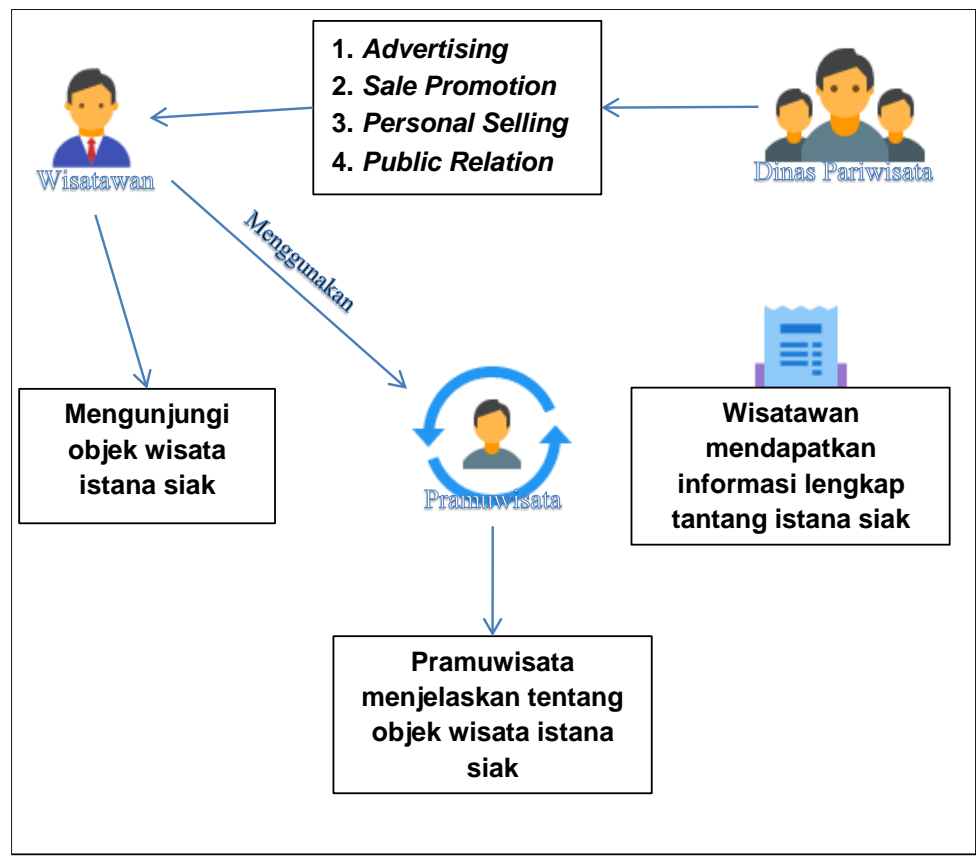

Gambar 1. Ilustrasi sistem yang sedang berjalan

\section{C.2. Sistem Usulan}

Aplikasi Mobile Tour System untuk memberikan informasi tentang objek wisata istana siak yang rancanag menggunakan aplikasi berbasiskan android mobile application dengan memanfaatkan teknlogi QR Code. Pada dasarnya aplikasi ini memudahkan user ketika ingin mendapatkan informasi tentang objek wisata istana siak secara cepat. 
Aplikasi yang dikembangkan mampu melakukan scan terhadap objek-objek yang ada dalam istana siak, pengunjung cukup melakukan scan pada $Q R$ Code objek maka Aplikasi akan langsung memberikan penjelasan informasi tantang objek tersebut tanpa meminta penjelasan dari pramuwisata yang ada dalam isata siak.

\section{C.3. Analisis Kebutuhan Fungsional Sistem}

Kebutuhan fungsional sistem dibagi menjadi dua, yaitu kebutuhan fungsional untuk sistem back end dan kebutuhan fungsional untuk sistem front end. Kebutuhan fungsional sistem back end dapat dilihat pada Gambar 2 sedangkan kebutuhan fungsional untuk sistem front end dapat dilihat pada Gambar 3.

\section{C.4. Class Diagram}

Class Diagram merupakan diagram yang menunjukan class yang ada di sistem dan hubungannya secara logic. Class diagram yang dibuat pada tahap design ini, merupakan deskripsi lengkap dari class-class yang ditangani oleh sistem, dimana masing-masing class telah dilengkapi dengan atribut dan operasi-operasi yang diperlukan. Berikut adalah Gambar 4.

\section{C.5. Arsitektur Jaringan}

Arsitektur sistem dapat dilihat pada Gambar 5. Arsitektur sistem yang dibangun adalah menggunkan client-server, pada arsitektur aplikasi tersebut adalah:

(1) Admin melakukan input semu data dalam aplikasi melalui sistem frontend kemudian disimpan kedalam server.

(2) Wisatawan membuka aplikasi menggunakan koneksi internet, maka aplikasi akan mmanggil data yang tersimpan kedalam server.

(3) Aplikasi menggunakan teknologi QR Code dan Direction maps.

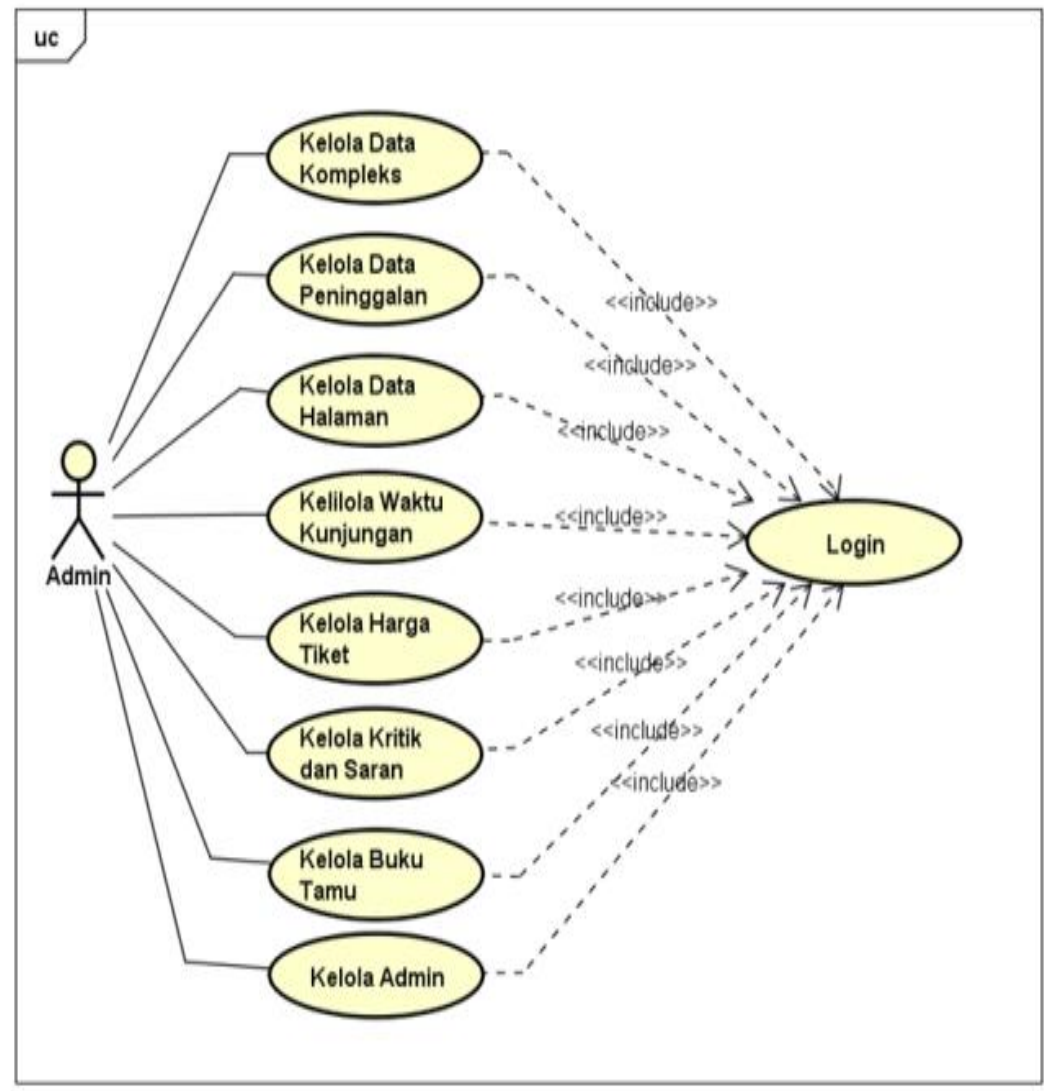

Gambar 2. Use case diagram back end 


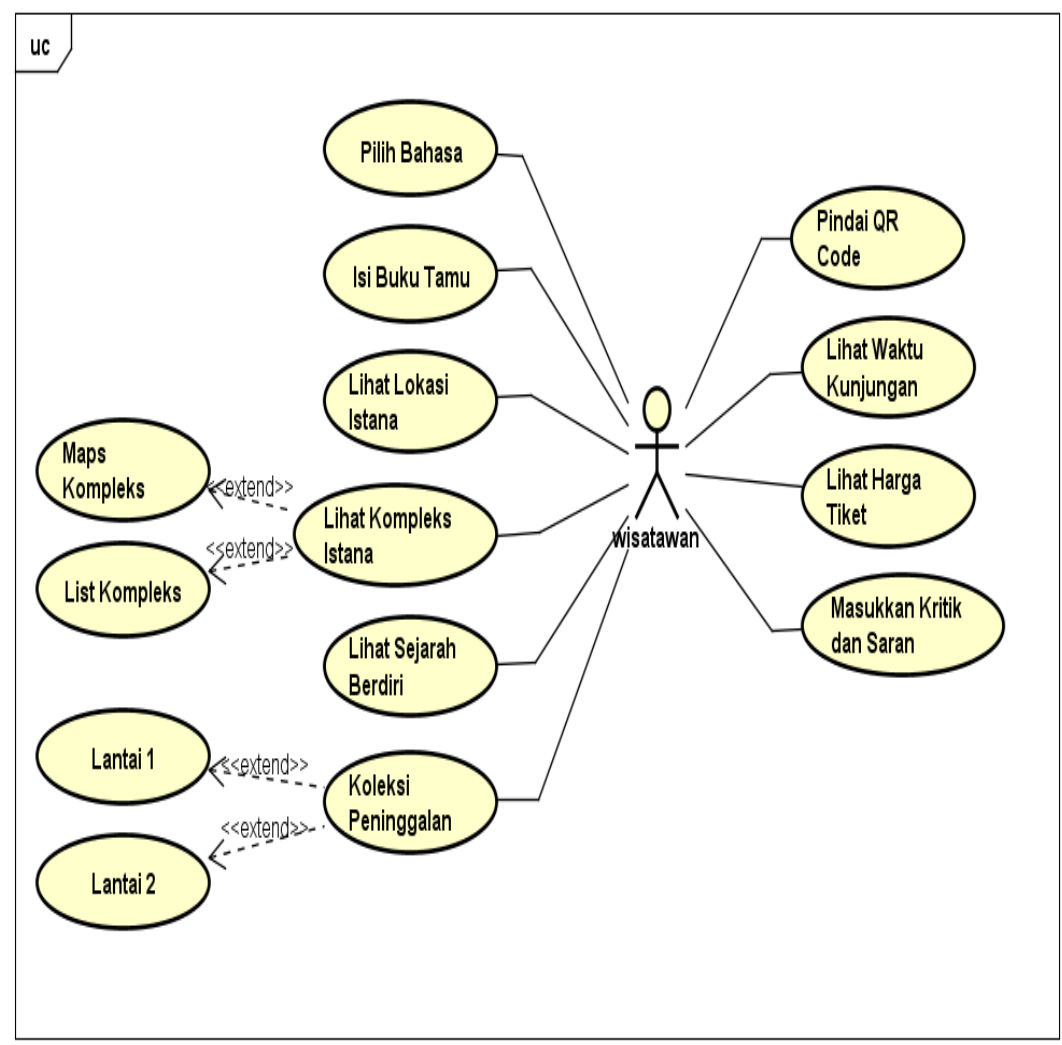

Gambar 3. Use case untuk front end

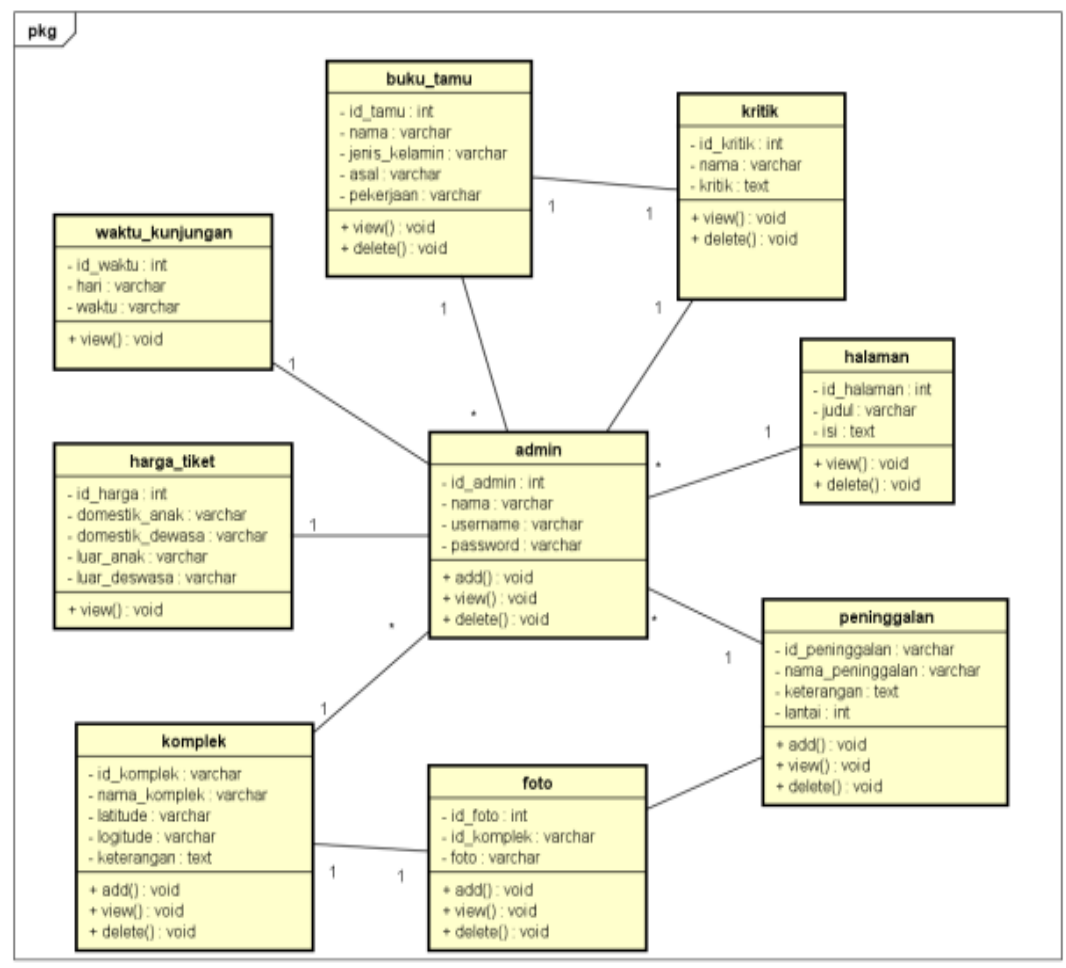

Gambar 4. Class diagram

\section{C.6. Implementasi}

Implementasi merupakan penulisan kode program kelanjutan dari proses perancangan yang diimplementasikan ke situasi nyata, sehingga sistem dapat memenuhi kebutuhan user. Batasan implementasi adalah sebagai berikut:

(1) Sistem yang dibagun menggunakan flatform berbasis android 5.0 lolipop. 
(2) Sistem memiliki sistem backend yakni pengelola Istana Siak sedangkan sistem frontend yakni wistawan ataupun masayarakat umum.

(3) Aplikasi yang digunakan dalam membangun dan mengembangkan aplikasi mobile tour system adalah Android Studio 2.3.3

(4) Sistem back end menggunakan bahasa pemrograman PHP dan menggunanakan basis data MySQL
(5) Dalam memandu wisatawan aplikasi dapat memindai QR Code dalam mengidentifikasikan setiap objek yang ada dalam istana siak.

Interface waktu kunjungan dapat dilihat pada Gambar 6. Interface menu data komplek dapat dilihat pada Gambar 7. Interface menu harga tiket dapat dilihat pada Gambar 8.

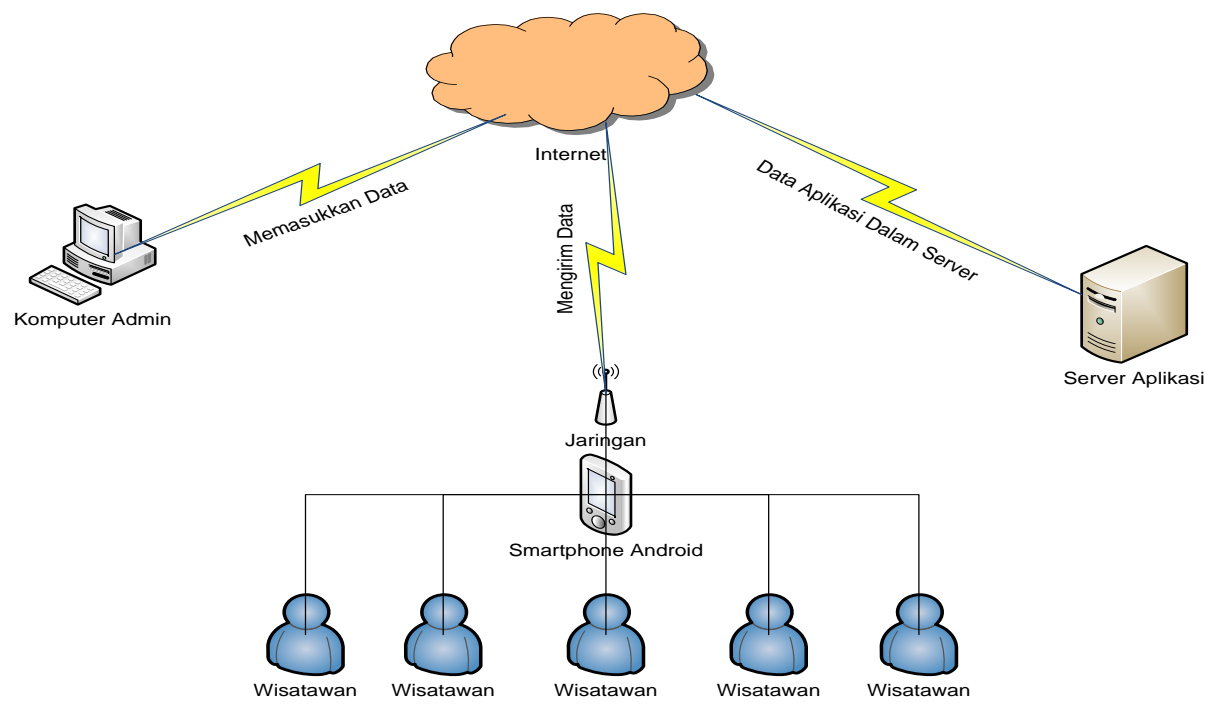

Gambar 5. Arsitektur sistem
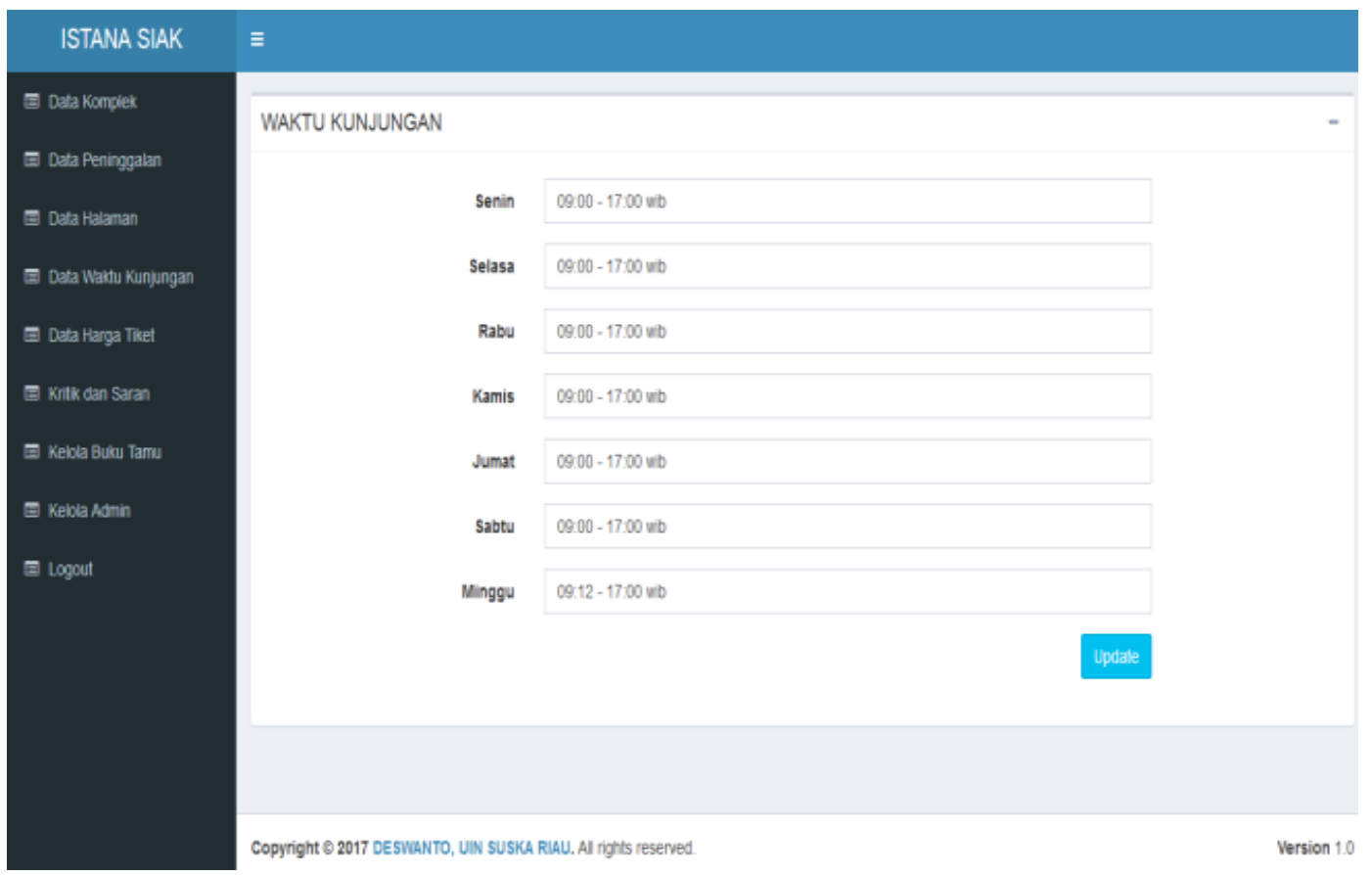

Gambar 6. Data waktu kunjungan 
Jurnal Ilmiah Rekayasa dan Manajemen Sistem Informasi, Vol. 4, No. 2, Agustus 2018, Hal. 172-178 e-ISSN 2502-8995, p-ISSN 2460-8181

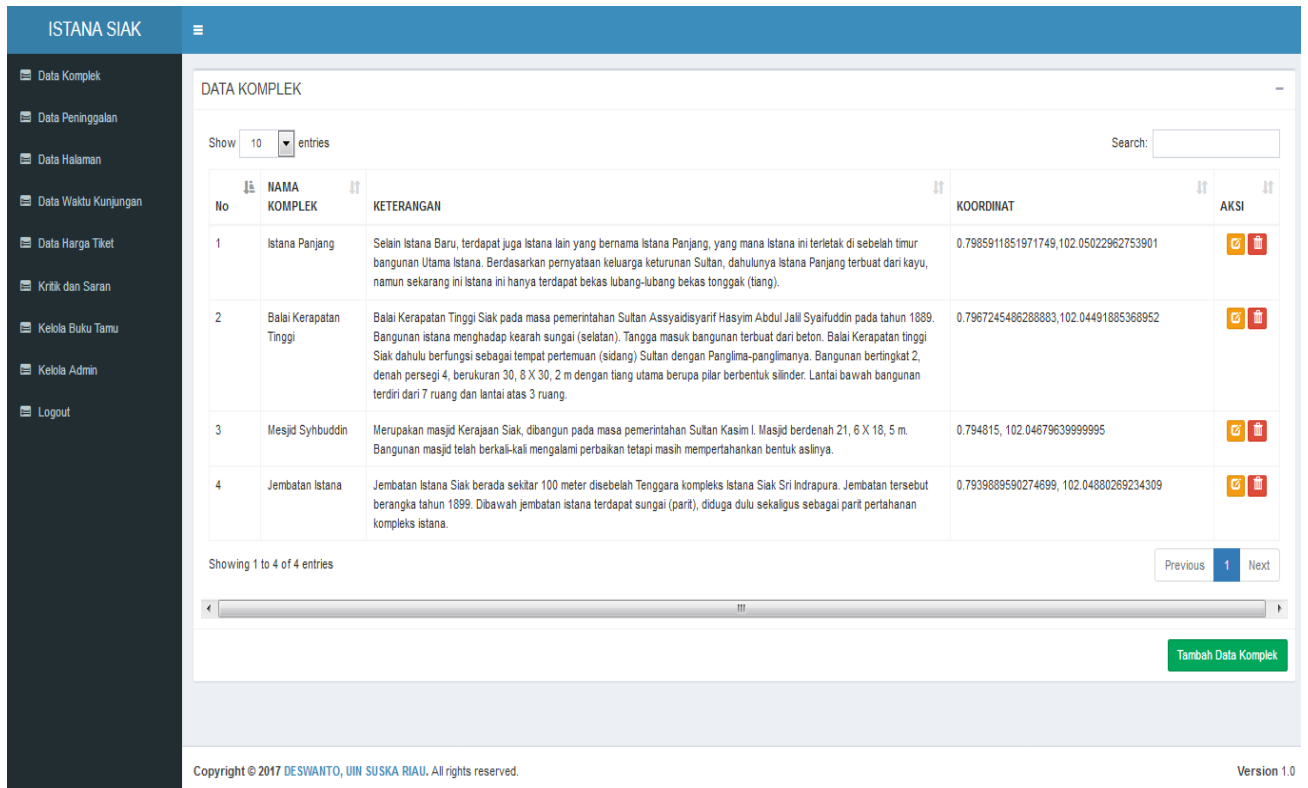

Gambar 7. Menu data komplek

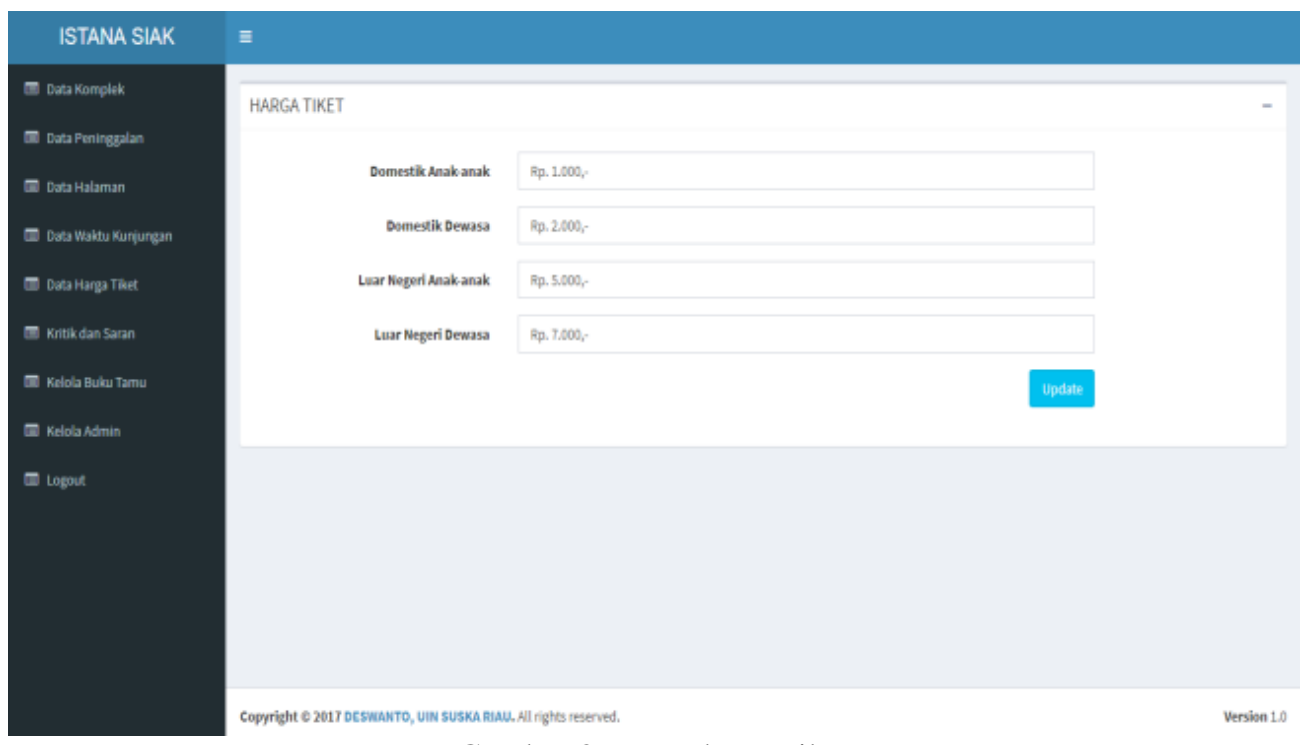

Gambar 8. Menu harga tiket

\section{C.7. Pengujian Sistem}

Hasil pengujian blackbox pada sistem back end dapat dilihat pada Tabel 1. Hasil pengujian blackbox pada aplikasi front end dapat dilihat pada Tabel 2.

Tabel 1. Hasil pengujian blackbox sistem back end

\begin{tabular}{clll}
\hline \multirow{2}{*}{ Penguji } & \multicolumn{2}{l}{ Modul Sistem } & $\begin{array}{l}\text { Persentase } \\
\text { Keberhasilan }\end{array}$ \\
\cline { 2 - 3 } & $\begin{array}{l}\text { Modul } \\
\text { Eror }\end{array}$ & $\begin{array}{l}\text { Modul } \\
\text { Berhasil }\end{array}$ & \\
\cline { 2 - 3 } 1 & 0 & 10 & $100 \%$ \\
2 & 0 & 10 & $100 \%$ \\
3 & 0 & 10 & $100 \%$ \\
4 & 0 & 10 & $100 \%$ \\
5 & 0 & 10 & $100 \%$ \\
\multicolumn{2}{l}{ Rata-rata keberhasilan } & & $\mathbf{1 0 0 \%}$ \\
\hline
\end{tabular}

Tabel 2. Hasil pengujian blackbox aplikasi front end

\begin{tabular}{llll}
\hline Pend & & \\
\hline 1 & Oppo F1 & Android 5.1 & $100 \%$ \\
2 & Asus Z007 & Android 4.4.2 & $100 \%$ \\
3 & Zefone 2 Laser & Android 5.0.2 & $100 \%$ \\
4 & Oppo Neo 7, & Android 5.1 & $100 \%$ \\
5 & Oppo A57 & Android 6.0.1 & $100 \%$ \\
\hline \multicolumn{2}{l}{ Rata-rata keberhasilan } & & $\mathbf{1 0 0 \%}$ \\
\hline
\end{tabular}

Berdasarkan hasil Pengujuan UAT yang dilakukan pada sistem back end (web) dengan menyebarkan angket UAT kepada 10 responden diperoleh hasil tingkat penerimaan sistem 53,75\%. Sedangkan sistem berdasarkan hasil pengujian UAT pada aplikasi front end, didapat tingkat penerimaan pengguna aplikasi sangat baik, yaitu $70 \%$. 


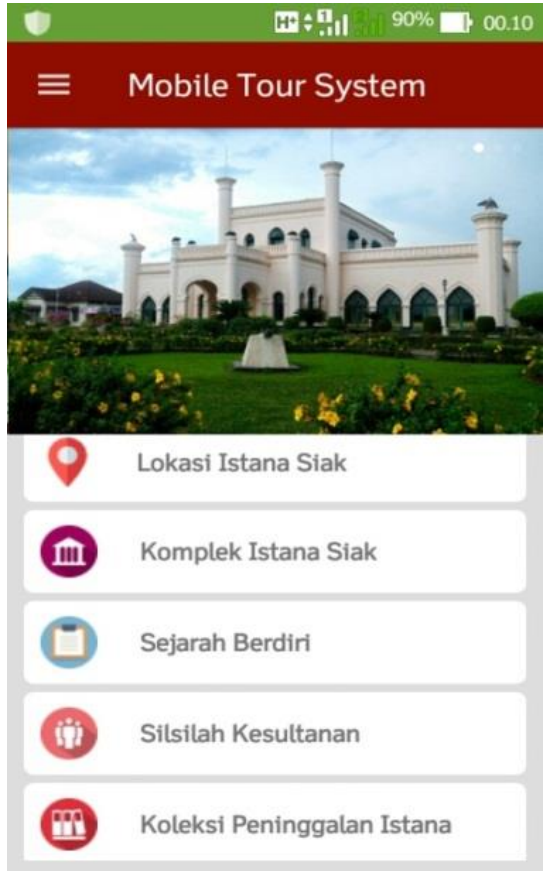

Gambar 9. Menu Utama

\section{KESIMPULAN}

Berdasarkan hasil analisa perancangan dan implementasi aplikasi mobile tour system objek wisata istana siak berbasis android dapat diambil kesimpulan sebagai berikut:.

(1) Wisatawan mampu mengakses informasi lokasi, sejarah serta koleksi peninggalan kerajaan siak menggunakan smartphone tanpa menggunakan pramuwisata yang ada karena aplikasi mampu berfungsi sebagai pramuwisata mobile.

(2) Dengan mengimplementasikan aplikasi mobile tour system ini mampu untuk memperkenalkan sejarah kerjaan siak kepada masyarakat luar agar sejarah yang ada dapat terjaga kelestarianya.

(3) Menerapkan aplikasi mobile tour system ini dapat mempermudah promosi objek wisata istana siak serta mampu mendukung program pemarintah dalam mengimplementasikan smart city di kabupaten siak
Untuk pengembangan kedepannya aplikasi yang dibuat perlu ditambah teknologi ugmented reality dan audio dalam memandu wistawan.

\section{REFRENSI}

[1] Aminah, S. (2015). Pelaksanaan Promosi Objek Istana Siak Provinsi Riau. Jurnal JOM FISIP Universitas Riau, Vol.2.

[2] Daulay, S. S. (2015). Hubungan antara QR Code dan Dunia Industri dan Perdagangan. Jakarta: Widyaiswara Pusdiklat Industri.

[3] Istiyanto, J. E. (2013). Pemrograman Smartphone Menggunakan SDK Android dan Hacking Android. Yogyakarta: Graha Ilmu.

[4] Mustaqbal, S., Firdaus, R. F., \& Rahmadi, H. (2015). Pengujian Aplikasi Menggunakan Black Box Testing Boundary Value Analysis. Jurnal Ilmiah Teknologi Informasi Terapan Vol 1, ISSN : 2407 - 3911.

[5] Musthofa, N. A., Mutrofin, S., \& Murtadho, A. M. (2016). Implementasi Quick Response (QR) Code Pada Aplikasi Validasi Dokumen Menggunakan Perancangan Unified Modelling Language. Jurnal Antivirus, Vol. 10 Universitas Pesantren Tinggi Darul 'Ulum, ISSN: 1978-5232.

[6] Nugraha, P., \& Munir, R. (2011). Pengembangan Aplikasi QR Code Generator dan QR Code Reader dari Data Berbentuk Image. Jurnal Konferensi Nasional Informatika, ISSN: 2087 - 3328.

[7] Prakarsa, A. D., \& Wibisono, W. (2013). Rancang Bangun Aplikasi Museum Tour Guide berbasis QR Code dan Ontology pada Mobile Phone. JURNAL TEKNIK POMITS Vol. 2, ISSN: 2337-3539.

[8] Rangsang, P. (2010). Mari Mengenal J2ME Java 2 Micro Edition. Jakarta: Prestasi Pustaka.

[9] Rizal, U., Susanty, W., \& Sutrisno. (2013). The Analysis Of History Collection System Based On Android martphone With QR Code Using QR Code. International Conference on Engineering and Technology Development Universitas Bandar Lampung, ISSN 2301-6590.

[10] Rosa, \& M.Shalahuddin. (2011). Rekayasa Perangkat Lunak. Bandung: Informatika.

[11] Tanjung, S. (2015). Analisis Kualitas Pelayanan Pramuwisata Di Istana Asserayah Hasyimiah Siak Sri Indrapura. Jurnal JOM FISIP Universitas Riau, Vol.7.

[12] Telaumbanua, K., \& Zai, A. (2013). Rancang Bangun Aplikasi Mobile Tour System (MTS) Berbasis Smartphone Android Untuk Pemandu Pariwisata Kota Medan. JSM STMIK MICROSKILL Vol 14, ISSN 1412-0100. 